\title{
津波を受けた水田土袞塩分の経時変化 TEMPORAL CHANGES IN SOIL SALINITY IN A TSUNAMI-AFFECTED RICE FIELD
}

\author{
寺崎寛章 ${ }^{1}$ ・草間政寛 ${ }^{2} \cdot$ 藤本明宏 $^{3} \cdot$ 福原輝幸 $^{4}$ \\ Hiroaki TERASAKI ${ }^{1}$, Masahiro KUSAMA ${ }^{2}$, Akihiro FUJIMOTO ${ }^{3}$ and Teruyuki FUKUHARA ${ }^{4}$ \\ ${ }^{1}$ 正会員工博 福井大学大学院 工学研究科 ( $9910-8507$ 福井県福井市文京3丁目9番1号) \\ 2 正会員 工修 株式会社エコ・プランナー（†918-8026 福井県福井市渕2丁目1811番地 Y2ビル3F） \\ 3正会員 工博 土木研究所寒地土木研究所 ( \\ $4^{4}$ 正会員 工博 福井大学大学院 工学研究科 (广910-8507 福井県福井市文京3丁目9番1号)
}

\begin{abstract}
A field test was conducted in a tsunami-affected paddy field in Natori city, Miyagi prefecture to understand temporal changes in soil salinity over the past 27 months and to collect information about the desalinization in the near future. Vertical profiles of the soil salinity and water content were obtained by TDR and four-electrode sensors installed down to a depth of $0.6 \mathrm{~m}$ below the paddy soil surface near our micrometeorological station. Salt mass in the soil up to $200 \mathrm{~mm}$ from the soil surface varied greatly due to eluviation of salt from the soil by rainfall and due to re-adsorption by the drying of the soil surface. Salt movement in the soil deeper than $200 \mathrm{~mm}$ was, however, hardly observed for about one month to two years. $\mathrm{Cl}^{-}$concentration in the soil was reduced to below the allowable concentration of rice planting about 400 days after the tsunami attack by runoff from the paddy field due to rainfall. It is seen from the above results that the salt removal of saline soil surface layer of $200 \mathrm{~mm}$ is effective for the desalinization.
\end{abstract}

Key Words : Salinization, Tsunami, salt movement, paddy soil, Miyagi prefecture

\section{1. はじめに}

2011年3月11日の東日本大震災での被害は土木関連分 野だけでも，建物倒壊，液状化，地盤沈下および放射能 污染など多方面にわたっている. 中でも津波(海水)によ る農地の塩害 (土壌中の過剩な塩類に起因寸る作物の生 育障害) は深刻である. 被害面積は岩手県，宮城県およ び福島県を中心に約 2.4 万haに達し，耕地面積の約 $2.6 \%$ に相当する (表-1を参照 $)^{1)}$. 特に宮城県の被害は最も広 範囲で約 1.5 万ha(当県耕地面積の約 $11 \%$ に相当)に及び, その約 $85 \%$ 方水田であった.

現在, 塩害水田では除塩のために縦浸透法(淡水によ るリーチング), 表土削除および弾丸暗渠の施工など2が 進められている. 除塩には一般的に多くの時間およびコ ストを要するために，宮城県では2013年3月時点で復旧 工事の着手率が70\%を超えたものの3)，平成24年度まで の営農再開可能面積は全体の約 $46 \%$ に留まる ${ }^{4)}$. また, 海岸近くの一部の農地では, 排水不良, 地下水の塩性化, 塩性地下水の噴出, 作土層の流出および高塩濃度土壤の 堆積などが除塩工事を難航させている。これより，沿岸
部での除塩完了および営農再開には，今まで以上の時間 および労力を要すると推察される.

例えば，筆者らが2011年8月から定期的に土䁃塩害調 查)を実施している宮城県名取市小塚原南地区では, 津 波から約2年6r月が経過した2013年9月時点においても， 未だ除塩は行われていない. 同地区の農家へのアンケー トのからは，除塩工事の遅れの夕ならず，営農再開時期， 除塩効果に関する情報不足を指摘する声が聞かれた。

過去に逆れば，日本では昭和34年の伊勢湾台風，昭和 58 年の日本海中部地震，平成11年の台風18号および平成 16年の台風16号による高潮で水田土壤の塩性化が報告さ れているフ ドネシア ${ }^{15}$ において津波による塩害の研究が行われてい るが，長期にわたって水田土袞中の塩分動態を調べた研 究は少ない，今後の営農再開に向けては除塩工事前の農 地での塩移動に関するデータ，例えば，除去すべき塩害 土壤の厚さや塩性地下水(あるいは海水)による下方から の塩分供給の有無などが，除塩工事の設計や塩害再発防 止の観点から重要となる.

そこで本研究では, 除塩工事前の名取市小塚原南地区 の水田を対象として, 今後実施される除塩の効率化に供 
表-1 東日本大震災による農地冠水被害

\begin{tabular}{|c||r|r|r|r|r|}
\hline \multirow{2}{*}{ 県名 } & 耕地面積 & \multirow{2}{*}{$\begin{array}{c}\text { 冠水面積 } \\
\text { (ha)※2011年 }\end{array}$} & \multicolumn{1}{|c|}{$\begin{array}{c}\text { 面積率 } \\
\text { (ha) }\end{array}$} & \multicolumn{2}{|c|}{ 冠水面積内訳 } \\
\cline { 5 - 6 } & (h) & 田(ha) & 畑(ha) \\
\hline \hline 青森県 & 156,800 & 79 & 0.1 & 76 & 3 \\
\hline 岩手県 & 153,900 & 1,838 & 1.2 & 1,172 & 666 \\
\hline 宮城県 & 136,300 & 15,002 & 11.0 & 12,685 & 2,317 \\
\hline 福島県 & 149,900 & 5,923 & 4.0 & 5,588 & 335 \\
\hline 茨城県 & 175,200 & 531 & 0.3 & 525 & 6 \\
\hline 千葉県 & 128,800 & 227 & 0.2 & 105 & 122 \\
\hline \hline 合計 & 900,900 & 23,600 & 2.6 & 20,151 & 3,449 \\
\hline
\end{tabular}

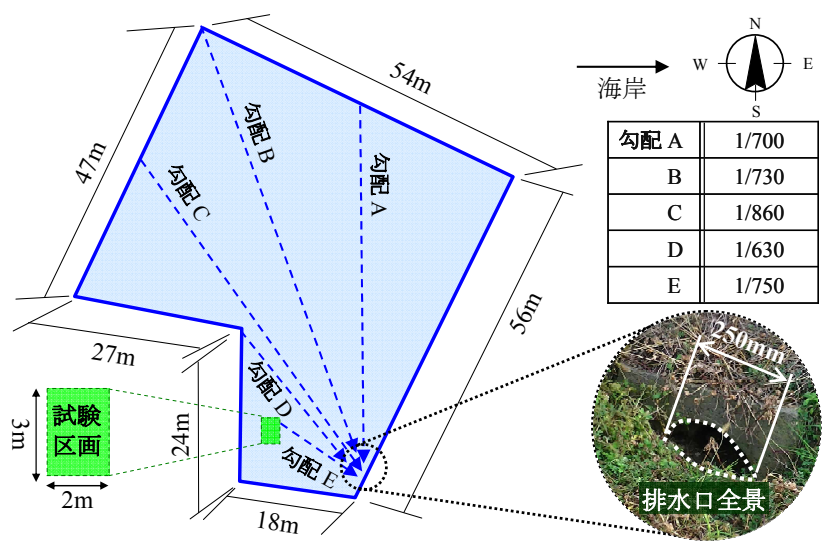

図-2＼cjkstart調査地の水田構造および勾配

する塩害土袞のデータ蓄積および分析を目的に，約 2 年 3ヶ月にわたって土壤中の塩分動態を調查したので，そ の結果をここに報告する.

\section{2. 野外塩移動モニタリング調査概要}

\section{（1）津波の被災状況}

稲作を中心とした農業が盛んな名取市小塚原南地区は 海岸から2〜3kmの沿岸域にあり，海抜はおよそ1〜2mで ある. 図-1に示寸ように同地区の津波浸水高㬏約2〜 $3 \mathrm{~m}$ であり, ほぼ全ての農地では大量の海水が浸入して, 污泥の堆積, 多数の瓦礫の残留, 地下水の塩性化および 排水設備の破損・埋没などが確認された。

\section{（2）調査概要}

野外塩移動モニタリング調査は田畑に囲まれた小塚原 汐入の水田(約 $0.26 \mathrm{ha}$ )にて行われた. 図-2は調查地の水 田構造および勾配を示す，従来，調査地には暗渠管はな く, 東南側 (海側) に明渠管 (直径 $\phi 250 \mathrm{~mm}$ ) が設置されて いるが，津波発生以降は明渠管の約 $1 / 2 \sim 2 / 3$ が土に埋 没し，排水不良に陥っている．なお，津波発生以降の水 田は手付かずのままであり，人為的な灌水および排水は ない. 水田勾配は図中に示寸ようにバラツキがあるもの

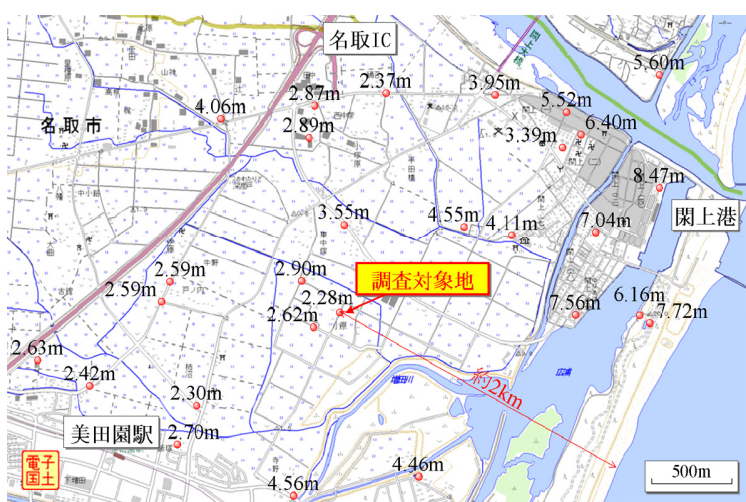

図-1＼cjkstart調查地周辺の津波浸水高

表-2 調査地の土袞物性

\begin{tabular}{|l||c|c|c|c|}
\hline 物性值/分類 & 堆積層 & 海砂層 & 作土層 & 耕盤層 \\
\hline \hline $\begin{array}{l}\text { 深さ (土層厚 }) \\
(\mathrm{mm})\end{array}$ & $\begin{array}{c}0 \sim 30 \\
(30)\end{array}$ & $\begin{array}{c}30 \sim 40 \\
(10)\end{array}$ & $\begin{array}{c}40 \sim 150 \\
(110)\end{array}$ & $\begin{array}{c}150 \sim 600 \\
(450)\end{array}$ \\
\hline $\begin{array}{l}\text { 飽和透水係数 } \\
(\mathrm{cm} / \mathrm{sec})\end{array}$ & $1.52 \times 10^{4}$ & $4.06 \times 10^{-3}$ & $4.16 \times 10^{-6}$ & $8.51 \times 10^{-6}$ \\
\hline $\begin{array}{l}50 \% \text { 粒径 } \\
(\mathrm{mm})\end{array}$ & 0.32 & - & 0.032 & 0.028 \\
\hline $\begin{array}{l}10 \% \text { 粒径 } \\
(\mathrm{mm})\end{array}$ & - & - & 0.0014 & 0.0024 \\
\hline 土㙴分類 & $\begin{array}{l}\text { 礫混じり } \\
\text { 細粒分質砂 }\end{array}$ & - & 砂質細粒土 & 砂質細粒土 \\
\hline
\end{tabular}

の，約 $1 / 600 〜 1 / 900$ で明渠に向かって排水されている. また，冠水時を除けば，塩分が試験区画に流入すること はない。土壤物性は表-2に示寸通り，地表には約 $40 \mathrm{~mm}$ の污泥土砂が堆積し，その下に約 $110 \mathrm{~mm}$ 厚の作土層, 約 $450 \mathrm{~mm}$ 厚の耕盤層(粘土層)がある.

調査は主として気象観測および土袞データ測定に大別 される (図-3を参照)。気象観測では，放射収支計 (Kipp\&Zonen製)，三杯式風速計(Davis製)，転倒ます型 雨量計 (竹田計器工業製), 熱電対および気温·湿度セン サー(Vaisala製)を用いた。放射収支計および二杯式風速 計は地上 $2.0 \mathrm{~m} に$, 熱電対および気温・湿度センサーは $1.5 \mathrm{~m}$ に，それぞれ設置した。

土壤データ測定のために, 熱電対, TDR方式土袞水分 センサー(東北電子製，ロッド長： $150 \mathrm{~mm}$ ， ロッド直 径 : $2 \mathrm{~mm}$, 以下, 水分センサー)および塩分 4 極センサー （サンケイ理化製，ロッド長 : 50mm，ロッド直径 : $5 \mathrm{~mm}$, 以下，塩分センサー)を用いた. 水分および塩分センサー は土壤体積含水率 $\theta\left(\mathrm{m}^{3} / \mathrm{m}^{3}\right)$ および塩濃度 $C\left(\mathrm{~kg} / \mathrm{m}^{3}\right)$ に依 存することから, 事前に調查地の水田土袞を用いて, 井 上勇に倣って校正試験を行い，水田土壤の $\theta$ および $C$ を 測定した。

次に，実験方法を述べる，土壌を縦，横，深さともに $0.6 \mathrm{~m}$ ま゙掘削し, 熱電対, 水分センサーおよび塩分セン サーをそれぞれ，図-3に示すように地表面下 $20 \mathrm{~mm}$ ， 


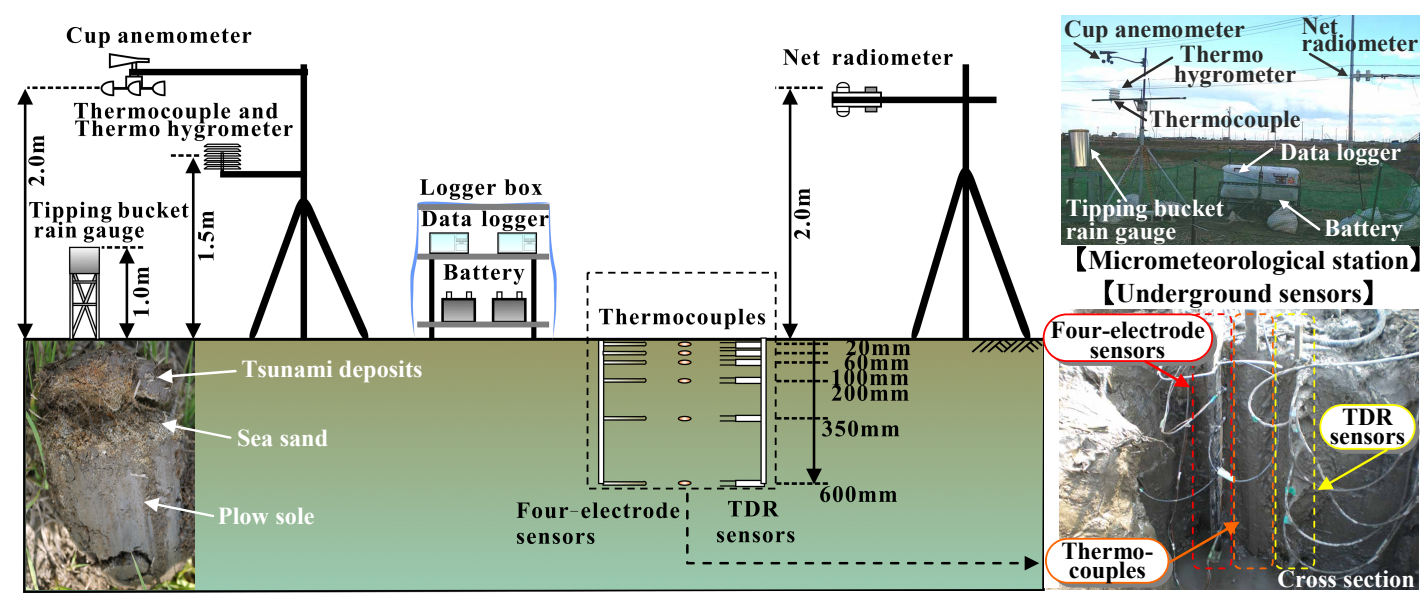

図-3＼cjkstart野外塩移動モニタリング調査概要

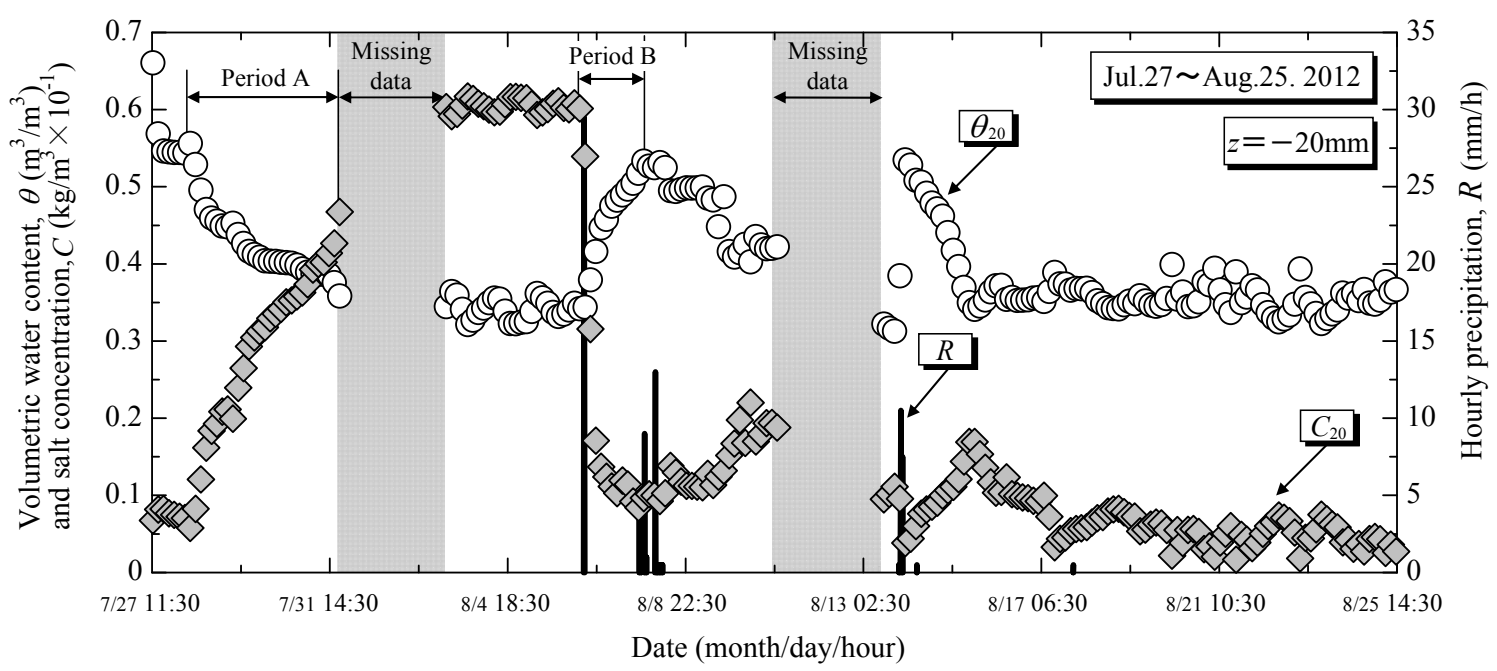

図-4 2012年7月27日から8月25日における地表近傍(地表面下20mm)の水分および塩分の挙動

60mm，100mm，200mm，350mmおよび600mmの深さに 埋設し，1年以上にわたる長期の塩分動態を調べた。ま た，鋼製土壌採取器(オーガー)を用いて地表面から深さ $600 \mathrm{~mm}$ までの土壌を定期的に採取し，深度別に $\theta, C お$ よび $\mathrm{Cl}^{-}$(塩素イオン) 濃度 (乾燥土壌 $100 \mathrm{~g}$ 当たりの $\mathrm{Cl}^{-}$質 量， $\mathrm{mg} / 100 \mathrm{~g}$ )をそれぞれ測定した。 なお，データ収集 (30分間隔) には2台のデータロガー(Campbell Scienceお よびMCS製)および台のカーバッテリーを用いた.

\section{3．野外塩移動モニタリング調査結果}

\section{（1）蒸発·乾燥および降雨·浸透に伴う水分および塩移動}

図-4は2012年7月27日から8月25日における蒸発・乾燥 および降雨・浸透に伴う地表近傍(地表面下 $20 \mathrm{~mm}$ : 深さ $z=-20 \mathrm{~mm})$ の水分および塩分の挙動を示す. プロット

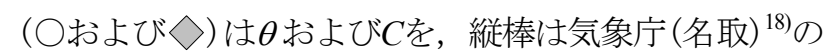
時間降水量 $R(\mathrm{~mm} / \mathrm{hr})$ をそれぞれ示す。以下，論文中の 下添え字の数字は測定深さ $(\mathrm{mm})$ を示す.

日最高気温 $33.9^{\circ} \mathrm{C}$ ，日最大日射量 $884 \mathrm{~W} / \mathrm{m}^{2}$ を記録した
期間A (7月28日9:00から31日21:00)において，蒸発・乾燥 により $\theta_{20}$ は時間とともに0.55から0.37まで急激に低下し た. 一方， $C_{20}$ は $\theta_{20}$ と逆相関を示し，期間内で急上昇し， 最高 $4.8 \%$ を記録した。期間B 8 月 6 日 13:00から同日 17:00)では月間最大時間降水量 $(29.5 \mathrm{~mm} / \mathrm{h})$ を記録し，水 田に数 $\mathrm{cm}$ の冠水が観られた。この期間， $\theta_{20}$ は0.34から 0.52 まで上昇する一方で， $C_{20}$ は $6.0 \%$ から $1.0 \%$ まで急激 に低下した。

以上より，土壌表面近傍では蒸発・乾燥に伴う塩分濃 縮と降雨・浸透に伴う塩分希釈が確認できた。

図-5は代表的な蒸発・乾燥期間 (2012年7月27日12:00か ら8月3日12:00) および降雨・浸透期間(2012年8月6日 12:00 から8月7日20:00) における土壌塩濃度鉛直分布の経時変 化を示す．7月27日12:00には， $C_{20}$ が最も高く，0.62\%で あった. その後, 蒸発·乾燥に伴い $C_{20}$ は24時間で最大約 $1.5 \%$ 増加し，8月 3 日に約 $6.0 \%$ に達した． $C_{60}$ は同期間中 に僅か $0.24 \%$ 増加したが，それ以深で殆ど変化は見られ なかった. これは表-2からも分かるように，150mm以深 では粒径が小さく，透水性が非常に低い粘土で構成され ていること, および塩濃度勾配が十分小さい結果, 塩分 
Salt concentration, $C(\%)$

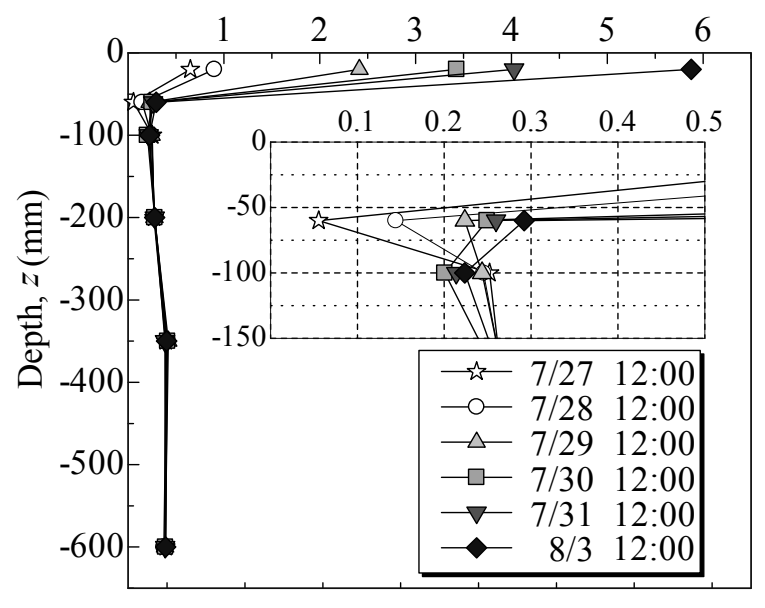

Salt concentration, $C(\%)$

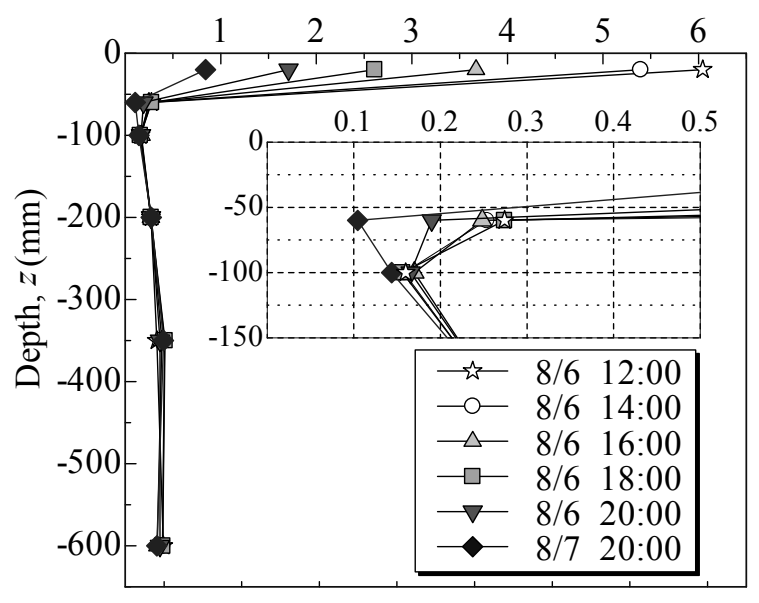

図-5 代表的な蒸発・乾燥期間 (左)および降雨・浸透期間 (右)における土壌塩濃度鉛直分布の変化の一例

は殆ど移動しなかったと推察される.

その後，8月6日の降雨・浸透期間において $C_{20}$ は初め約 6.0\%であったが，降雨(13:00) 直後から急激に低下し，5 時間後 (18:00)には半分以下の $2.6 \%$ となった. 降雨後も $C_{20}$ が低下した理由は，排水不良によって残存した貯留 水への土畩塩の溶脱が原因と推察される. 結果, 図-5に おける $z=-20 \mathrm{~mm}$ の塩分希釈速度は塩分濃縮速度の約6倍 であった. これより, 浸透による塩の下向きフラックス は蒸発に伴う塩の上向きフラックスよりも大きいことは 明らかである. なお，降雨に伴う水分浸透は地表面下 100mmに達しておらず，塩移動の範囲は蒸発のそれと大 差無い.

以上，1週間程度の短期的な観察によると蒸発および 降雨に伴う塩移動は地表から60mmまでであり，これは 相対的に大きな透水係数を有する表層の範囲(表-2を参 照)にほぼ対応する.

\section{（2）土壤含塩量の季節変化特性}

次に，長期的な土壌中の塩分動態を考察する. 図-6は 2012年8月，12月および2013年4月，8月における土壌含 塩量 $M_{\text {salt }}\left(\mathrm{mg} / \mathrm{cm}^{3}\right)$ 鈆直分布を示す.シンボル $(\bigcirc)$ および $(|-|)$ は $M_{\text {salt }}$ の月間平均值 $M_{\text {salt }}^{\text {ave }}$ および各深さで測定され た值の範囲をそれぞれ示す. 2012年8月の乾期には $z=$ $-20 \mathrm{~mm} の M_{\text {salt }}\left(M_{\text {sal } 20}\right)$ が稲作許容值 $\left(=1.3 \mathrm{mg} / \mathrm{cm}^{3}\right.$, 稲作限 界 $\mathrm{Cl}^{-}$濃度 $\mathrm{Cl}^{-}$al $=100 \mathrm{mg} / 100 \mathrm{~g}$ 乾土 ${ }^{19)}$ および乾燥密度 $0.8 \mathrm{~g} / \mathrm{cm}^{3}$ に対する值) の約 1.8 倍の $2.3 \mathrm{mg} / \mathrm{cm}^{3}$ を記録したの に対して, 降雨時の $M_{\text {sal } 20}$ は検出限界以下となり, $M_{\text {salt }}$ の 変動幅は他のどの月よりも大きくなった. 一方, $100 \mathrm{~mm}$ 以深における $M_{\text {salt }}$ の変動幅は小さい.

4 月後の 12 月には降雨による土壌塩分の溶脱および 明渠から水田外部への排水に伴う塩の流出によって, $M_{\text {salt } 20}$ は最大 $0.58 \mathrm{mg} / \mathrm{cm}^{3}$ となり，8月のそれの約 $1 / 4$ と なった，その後の2013年4月の分布を見ると，12月のそ れと大差無い。これは1月から3月の間の降水量が僅か
$20 \mathrm{~mm}$ (2012年 8 月から 2013 年 7 月の一年間の降水量 (782mm)の約 $2.6 \%$ に相当)であり，降雨に伴う水田外 の塩分流出や下方への塩移動が無視できるほど小さかっ たためと推察される. 結果として2012年8月から2013年8 月までの1年間で，地表から深さ600 $\mathrm{mm} ま て ゙ の M_{\text {salt }}^{\text {ave }}$ の積分值 $\left(\Sigma M_{\text {salt }}\right)$ は $10.5 \mathrm{mg} / \mathrm{cm}^{2}$ から $5.7 \mathrm{mg} / \mathrm{cm}^{2}$ となり, 約半分と なった. また, 深さ $600 \mathrm{~mm} の M_{\text {salt }}$ の顕著な増加はなく, 600mm以深からの塩分供給はないと思われる.

土壌表層で $M_{\text {salt }}$ が大きく変動する原因を説明するため に，図-7に長期にわたる土壤内部への塩分浸透の代表例 (2012年8月と2013年5月の約1ヶ月間の代表的な $M_{\text {salt }}$ 鉛直 分布)を示す. 5月 30 日と 8 月 27 日は降雨によって表層土 壌が高含水状態にあった時の $M_{\text {salt }}$ 鉛直分布を，5月5日と 8月6日は逆に低含水状態にあった時の $M_{\text {sal }}$ 鉛直分布をそ れぞれ表す，図-7より，降雨による土壌塩分の溶脱と塩 の下方移動および蒸発による溶脱塩の再付着と塩の上方 移動が原因となって，深さ200mmまでの土壤で $M_{\text {salt }}$ は大 きく変動した(図中の↔で示す)。しかしながら，200mm 以深においては9ケ月の時差があるものの分布形の違い は殆どなく, 200mm以深への塩分浸透は無視できること が分かる.

以上より，1ヶ月から 2 年程度の長期観測から，当該調 査地における明瞭な鉛直方向の塩移動は, 地表から深さ 200mmまでに限られるとともに，1週間程度の短期の塩 移動範囲(地表から深さ $60 \mathrm{~mm}$ まで, 図-5を参照)よりも 約3倍拡大することが分かった.

\section{（3）根域 $C /$-濃度の長期変動}

次に稲の生育の観点から, 稲の根域 (地表から深さ $300 \mathrm{~mm}$ 程度 $\left.{ }^{20)}\right)$ における土壤中の総 $\mathrm{Cl}^{-}$濃度 $\mathrm{S} \mathrm{Cl}^{-}$の経時 変化を図-8に示す.プロット $(\bigcirc)$ は土壌サンプリング の值を示し, 曲線(実線)はプロットの近似を示す。な お，塗り潰しのプロット $\left(\right.$ ) は根域稲作許容值 $\Sigma C l_{a l}^{-}$を 


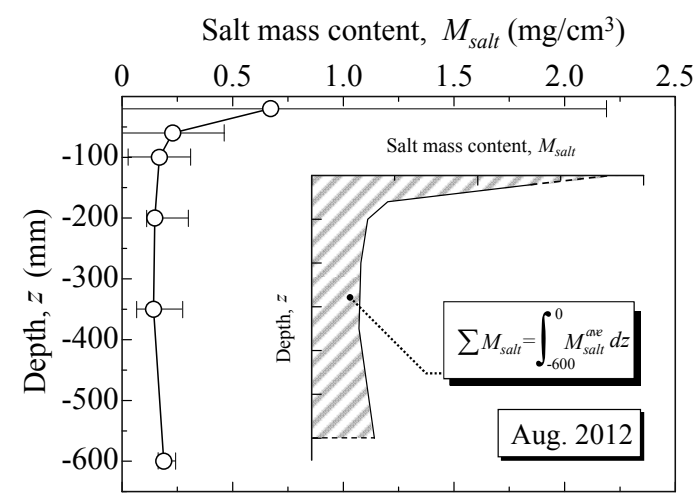

a) 2012年8月

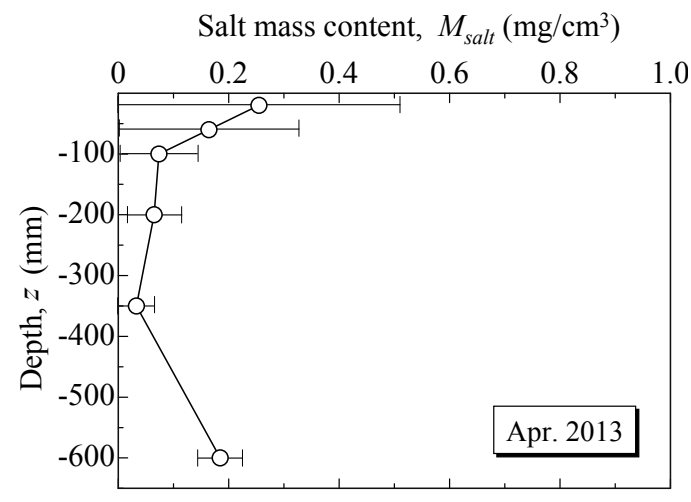

c) 2013 年 4 月

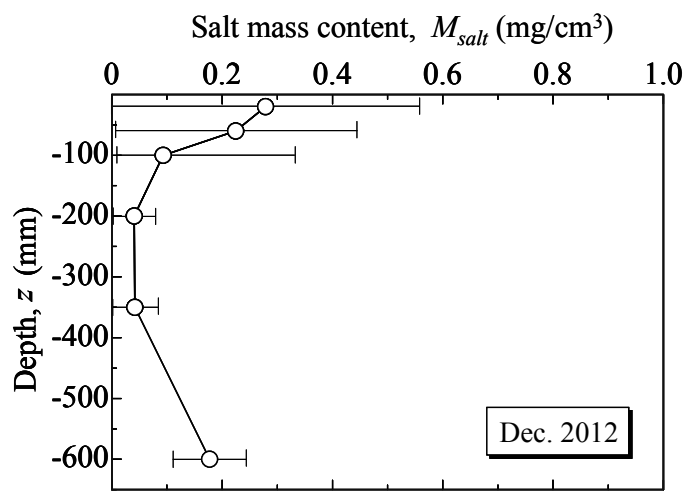

b） 2012年12月

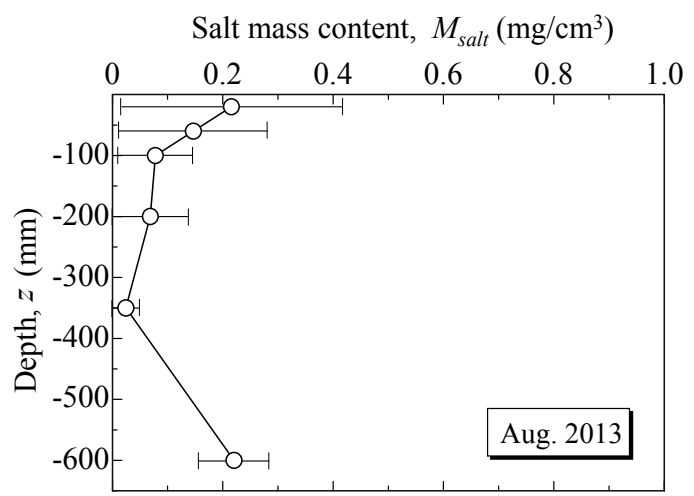

d） 2013 年 8 月

図-6 土㙥塩濃度鉛直分布の月間変化(2012年8月～2013年8月)

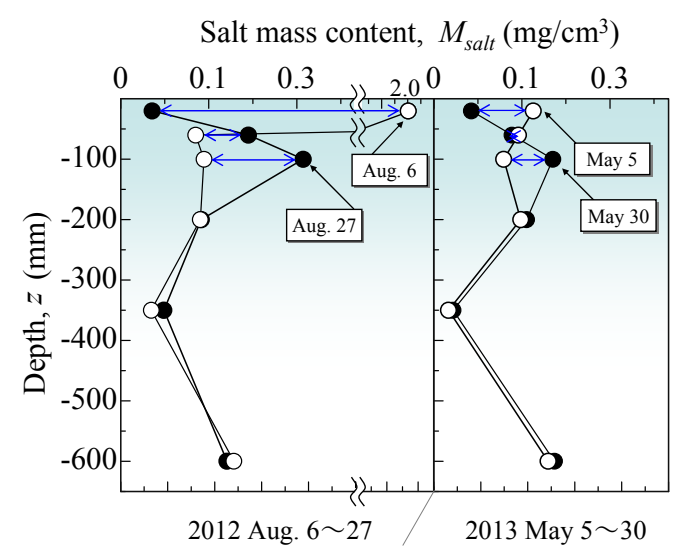

図-7 土壤内部への塩分浸透

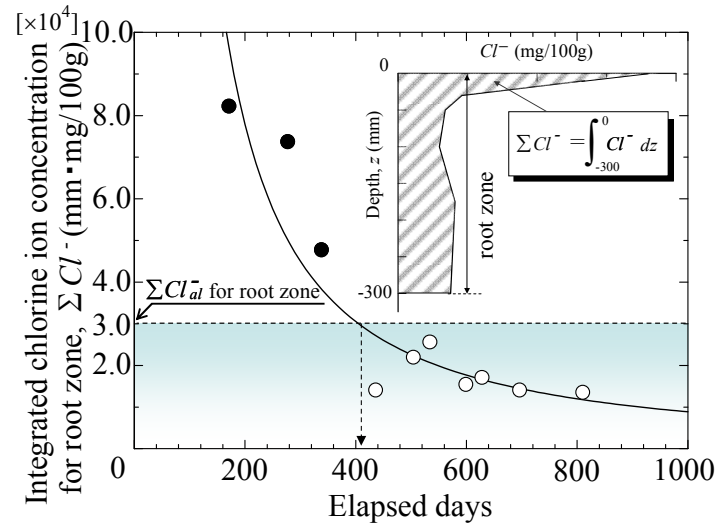

図-8＼cjkstart稲の根域における総 $C l$ 濃度の経時変化
超えたことを示す. ここで， $\Sigma \mathrm{Cl}_{\mathrm{al}}^{-}$は次式で与えられる.

$$
\Sigma C l_{a l}^{-}=\int_{-300}^{0} C l_{a l}^{-} d z
$$

よって, $\Sigma \mathrm{Cl}_{\mathrm{al}}^{-}=3.0 \times 10^{4} \mathrm{~mm} \cdot \mathrm{mg} / 100 \mathrm{~g}$ となる.

津波による浸水から約170日後の $\Sigma \mathrm{Cl}^{-}$は $\Sigma \mathrm{Cl}^{-}{ }_{a l}$ のおよ そ2.7倍となった. その後, $\Sigma \mathrm{Cl}^{-}$は指数関数的に低下し, た。 また，浸水から約400日後の $\sum \mathrm{Cl}^{-}$は全て $\Sigma C l_{a l}^{-}$を下 回った。 なお， $\Sigma \mathrm{Cl}^{-}$の減少は前節で述べたように，降 雨による水田からの排水に伴う塩分流出に起因すると推
察される.

以上の結果を踏まえて，図-9は当該水田土畩の除塩深 さの考え方を示す. 図-5および図-6より，海水の冠水期 間が短いほど除塩対象となる土壌層厚は薄くてすむこと が知れる. 除塩の目安として, 海水の冠水から1週間以 内であれば，地表面下 $60 \mathrm{~mm}$ までの土壤を対象に，1ケ月

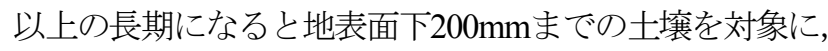
排土あるいは耕起や弾丸暗渠設置後の縦浸透法や溶出法 を実施することで，除塩効果が期待できる. 

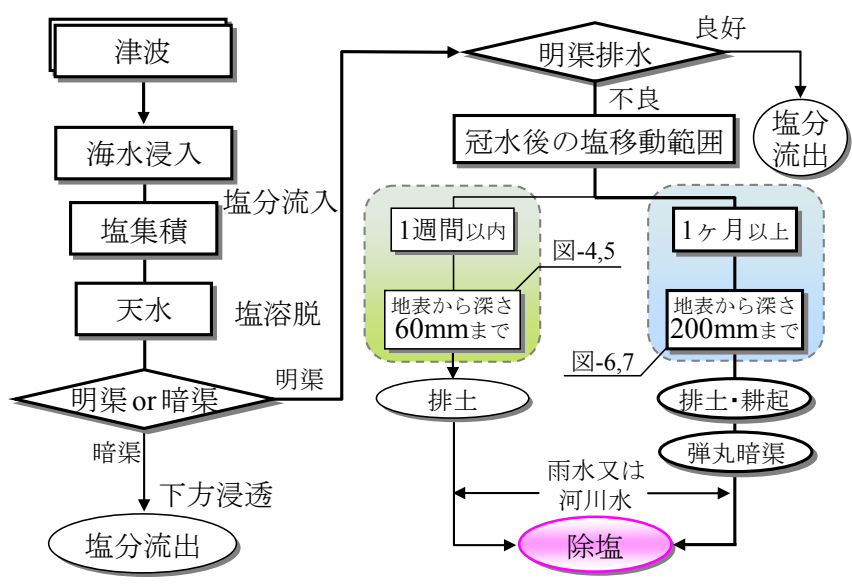

図-9 水田土袞中の塩移動を考慮した除塩深さ

\section{4. おわりに}

本研究では，今後始まる沿岸部の除塩工事の設計や塩 害の再発防止を最終目標に，除塩工事前の排水不良水田 土壤中の塩分動態を調べることを目的として，約2年3ケ 月にわたって野外塩移動モニタリング調査を行い，土壤 塩分動態を調べた.

その結果を以下に列挙する.

（1）土壌体積含水率と塩濃度は逆相関を示し, 今回の事 例では, 降雨による塩分希釈速度は蒸発による塩分 濃縮速度よりも約 6 倍速い。

（2）蒸発および降雨に伴う塩移動範囲は 1 週間以内であ れば地表から深さ $60 \mathrm{~mm}$ までの表層に限られる.

(3) 塩分の鉛直移動範囲は時間とともに拡大寸るが, 1 ケ月から 2 年間程度では地表から深さ $200 \mathrm{~mm}$ ま でに限られ，それ以深の塩移動は無視できる.

（4）(2)と(3)より海水の冠水から 1 週間以内であれば, 地表面下 $60 \mathrm{~mm}$ までの土壤が，1 ケ月以上の期間に なると地表面下 $200 \mathrm{~mm}$ までの土壌が，それぞれ排 土や耕起による除塩対象となる.

(5) 本調查地においては天水(雨水) 除塩により, 津波か ら約 400 日後に稲の根域(地表から深さ $300 \mathrm{~mm}$ まで

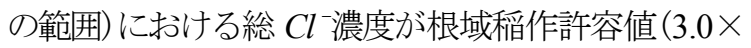
$10^{4} \mathrm{mg} \cdot \mathrm{mm} / 100 \mathrm{~g}$ )を下回った.

今後は除塩前の塩害水田土壤を対象に土壤中の熱・水 分および塩移動モデルを構築し，除塩シミュレーション を行い，除塩の効率化を図る.

謝辞 : 本研究は小塚原南農業復興組合代表 遠藤清氏の 多大なご協力と, 平成24年度 JSPS科研費 (23860024)を 受けて行われた。ここに記して深甚の謝意を表す。

\section{参考文献}

1) 農林水産省: 津波により流失や冠水等の被害を受けた農 地の推定面積 (http://www.maff.go.jp/j/press/nousin/sekkei/pdf/ 110329-02.pdf), 2013.

2) 農林水産省: 農地の除塩マニュアル (http : //www.maff.go.jp /j/press/nousin/sekkei/110624-01.pdf), 2011.

3) 宮城県: 復興の進捗状況 (平成 25 年 3 月 11 日), 2013.

4) 農林水産省 : 農業・農村の復興マスタープラン (http:/ www. maff.go.jp/jkanbo/joho/saigai/higai_taio/pdf/plan_2505.pdf) , 2013.

5) 寺崎寛章, 草間政寛, 福原輝幸 : 宮城県名取市, 岩沼市 および亘理町における津波後の水田土壌塩害調査，土木 学会第 67 回年次学術講演会講演概要集, CS10-017, pp. 33-34, 2012.

6) 寺崎寛章, 草間政寛, 福原輝幸 : 東日本大震災後の宮城 県名取市における除塩事業に関するアンケート，土木学 会第 68 回年次学術講演会講演概要集, VII-006, pp. 11-12, 2013.

7) 米田茂男 : 伊勢湾台風による冠潮塩害土壌について, 岡 山大学農学部学術報告, Vol. 18, pp. 51-60, 1961.

8) 三浦昌司，児玉徹，金田吉弘：日本海中部地震による津 波被害，農業技術，Vol. 39，No. 2，1984.

9) 河田直美, 有好利典, 大内英司: 平成 11 年台風 18 号による 塩害対策一3 年ぶりの実施一, 水と土, Vol. 121, pp. 10-17, 2000.

10）熊本県八代農業改良普及センター: 台風 18 号技術対策資 料集, pp. 1-51, 2001.

11) 香川県農業経営課：農地への海水の流入が農作物に及ぼ 寸影響とその対策，pp. 1-14， 2004.

12）中矢哲郎，丹治肇，桐博英 : 2004 年インド洋津波による 夕イ南部農村地帯の長期的被害調查, 海岸工学論文集, Vol. 53, pp. 1381-1385, 2006.

13) 久米崇, 梅津千恵子, K. Palanisami : 2004 年 12 月の巨大 津波によるインドタミルナドゥ州の農地における塩性化 被害と回復評価, 農業農村工学会論文集, Vol. 78, No. 2, pp. 83-88, 2010.

14) Raja, R., Chaudhuri, S. G., Ravisankar, N., Swarnam, T. P., Jayakumar, V. and Srivastava, R. C. : Salinity status of tsunamiaffected soil and water resources of South Andaman, India. Current Science, Vol. 96, pp. 152-156, 2009.

15) Agus, F., Rachman, A., Wahyunto, Ritung, S., Mcleod, M. and Slavich, P.: The dynamics of Tsunami affected soil properties in Aceh, Indonesia, Journal of Integrated Field Science, Vol. 9, pp. 11-20, 2012.

16）原口強, 岩松暉: 東日本大震災津波詳細地図 上巻 [青 森·岩手·宮城], 古今書院, pp. 76, 2011.

17) 井上光弘 : 塩分を含んだ砂に対する誘電率水分計の測定 精度の評価, 水文·水資源学会誌, Vol. 11，No. 6, pp. 555-564, 1998.

18) 気象庁: 気象統計情報(http://www.jma.go.jp/jma/menu/report. $\mathrm{html}), 2012$.

19）千葉県農林部農業改良課：千葉県農林公害ハンドブック 千葉県農林部農業改良課編, 1989.

20）川田信一郎 : 写真図説イネの根, 農山漁村文化協会, 1982.

(2013. 9. 30受付) 